\title{
PRODUCTIVITY AND ADAPTABILITY INDICES OF CORN HYBRIDS OF DIFFERENT GROUPS OF RIPENING
}

\section{Naidionov V. H.}

\section{INTRODUCTION}

Identification of corn genotypes by adaptability parameters should be performed according to the results of tests in an ecological gradient, which is formed by the means of agrotechnical measures and, as far as possible, most fully reflects the range of agroclimatic conditions of possible genotype propagation. The most informative quantification can be obtained on the basis of regression models and variance methods ${ }^{1}$.

Modern agro-economic conditions require a wide range of corn genotypes that have specific .adaptability to soil-climatic and technological factors. In recent years, a number of the hybrids have been created at the Institute of Irrigated Agriculture of NAAS, which are characterized by a wide range of vegetation periods duration and adaptability to agro-economic conditions $^{2}$. However, one of the problematic issues in crop production remains a considerable variation in genotype yields under different cultivation conditions ${ }^{3}$.

In the conditions of southern region of Ukraine, the main factor of the yield limitation is moisture. However, the use of optimal irrigation regimes has become economically unavailable for many farms due to high energy costs. That is why the development of water-saving technologies for corn cultivation has become the prerogative of research in the scientific institutions in southern region ${ }^{4}$.

1 Лавриненко Ю.А., Гудзь Ю.В. Теория и практика адаптивной селекции кукурузы. Херсон: Борисфен-полиграфсервис, 1997. 170 с.

2 Лавриненко Ю.О., Коковіхін С.В., Найдьонов В.Г., Нетреба О.О. Селекційнотехнологічні аспекти підвищення стійкості виробництва зерна кукурудзи в умовах південного Степу. Бюлетень Інституту зернового господарства. 2006. № 28-29. C. $136-143$.

${ }^{3}$ Олешко О.Г. Адаптивна характеристика гібридів кукурудзи, створених за участю лінії ДК 633/266-112. Бюлетень Інституту зернового господарства. 2003. № 21-22. С. 65-69.

${ }^{4}$ Писаренко П.В., Григоренко Є.Я., Лавриненко Ю.О., Писаренко В.А. Продуктивність гібридів кукурудзи при різних умовах зволоження та густоті стояння рослин. Наукові проблеми виробництва зерна в Україні та сучасні методи їх вирімення. Дніпропетровськ. 2000. C. 82-83. 


\section{Productivity of hybrids of different ripening groups and its variation depending on technology and weather conditions}

Field experiments with corn hybrids were conducted in the fields of the State Enterprise "Research Farm" Askaniiske "of Askanian State Agricultural Research Station of the Institute of Irrigated Agriculture of the National Academy of Agrarian Sciences of Ukraine, located in Kakhovka district of Kherson region in the Steppe of Ukraine.

The study of the response of individual genotypes of corn to water supply showed that there is a significant genotype-environment reaction, which can significantly change the ranking of hybrids in terms of yield (Table 1).

Table 1

Reaction of corn genotypes of different ripening groups by FAO on water supply and weather conditions of a year

\begin{tabular}{|c|c|c|c|c|c|c|}
\hline \multirow{2}{*}{$\begin{array}{l}\text { Genotype } \\
\text { No. }\end{array}$} & \multirow{2}{*}{$\begin{array}{l}\text { Hybrid } \\
\text { (Factor A) }\end{array}$} & \multirow{2}{*}{ FAO } & \multicolumn{3}{|c|}{$\begin{array}{l}\text { Grain yield (t/ha) depending on } \\
\text { the irrigation regime (Factor B)) }\end{array}$} & \multirow{2}{*}{$\begin{array}{c}\text { Average } \\
\text { by the } \\
\text { Factor } \\
\text { A }\end{array}$} \\
\hline & & & $\begin{array}{c}\text { Biologically } \\
\text { optimal }\end{array}$ & $\begin{array}{l}\text { Water- } \\
\text { saving }\end{array}$ & $\begin{array}{c}\text { Without } \\
\text { irrigation }\end{array}$ & \\
\hline 1 & Tendra & 190 & 9.23 & 8.78 & 4.30 & 7.44 \\
\hline 2 & $\begin{array}{l}\text { Borysfen } \\
\text { 191MV }\end{array}$ & 190 & 7.87 & 7.08 & 3.65 & 6.20 \\
\hline 3 & $\begin{array}{l}\text { Borysfen } \\
250 \mathrm{MV}\end{array}$ & 280 & 10.66 & 9.88 & 4.01 & 8.18 \\
\hline 4 & Syvash & 280 & 10.91 & 9.86 & 4.56 & 8.45 \\
\hline 5 & $\begin{array}{l}\text { Borysfen } \\
\text { 380MV }\end{array}$ & 320 & 10.86 & 9.72 & 3.43 & 8.00 \\
\hline 6 & Azov & 360 & 11.80 & 9.83 & 2.92 & 8.18 \\
\hline 7 & $\begin{array}{l}\text { Borysfen } \\
\text { 433MV }\end{array}$ & 430 & 12.07 & 9.59 & 2.78 & 8.15 \\
\hline 8 & $\begin{array}{l}\text { Borysfen } \\
600 \mathrm{MV}\end{array}$ & 550 & 13.33 & 7.67 & 2.11 & 7.70 \\
\hline \multicolumn{3}{|c|}{ Average by Factor B } & 10.84 & 9.05 & 3.47 & \\
\hline
\end{tabular}

It was determined that the highest yielding potential at the optimal irrigation regime resides to hybrids with FAO over 400 (12.0-13.3 t/ha). However, even at the water-saving regime of irrigation, there was a critical decrease in the yield of hybrids with FAO of more than 500, and the first places by the yield is occupied by the middle-early and middle-ripening hybrids.

Significant change in the ranking takes place under the cultivation technologies without irrigation. It should be noted that under favorable weather conditions, there was a significant increase in yield in the irrigated 
variants on the hybrids of all ripening groups, especially in the middle-late and late hybrids. In general, without irrigation in the sub-zone of southern Steppe, it is advisable to cultivate hybrids with FAO not exceeding 300.

The most versatile are middle-early hybrids, which quite efficiently use the autumn-winter moisture reserves, ripen rapidly in late August and have low grain moisture content. Such hybrids include Borysfen 250MV and Syvash. More early-ripening hybrids should only be used in water-saving technologies and on non-irrigated areas.

Hybrids with FAO exceeding 350 should be used at optimal irrigation and mineral nutrition because their yielding capacity does not have significant advantages over earlier genotypes and grain moisture has worse indices.

In dry weather conditions, the yield level of late hybrids may not be adequate to genotype potential. This leads to the fact that selection of highyielding FAO hybrids exceeding 400 in dry weather conditions may not be effective, and the most productive is FAO group 280-390, which, owing to their plasticity and less water consumption, provide the highest grain yield in such years.

Hybrids with FAO exceeding 500 have a high yielding potential, however, the strong negative response of these genotypes to environmental fluctuations results in a yield decrease below the level of earlier hybrids and places them outside the group of hybrids suitable for effective use in the irrigated conditions of southern Steppe at the current stage of development of agriculture.

The study of the share of influence of the studied factors on grain yield showed that the irrigation regime is a predominant one (Fig. 1). However, the presented dependence does not reflect the response of individual hybrids to the conditions of the year and agrotechnical background.

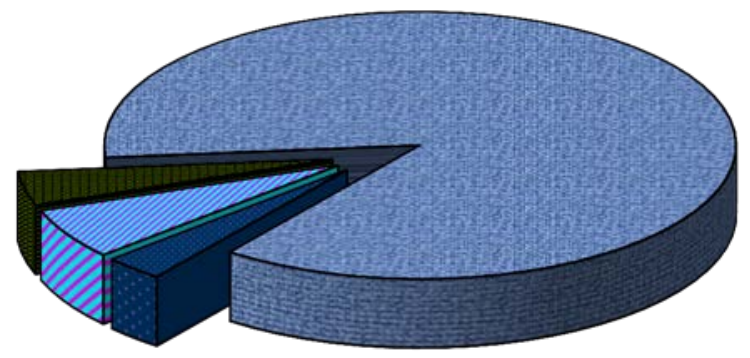

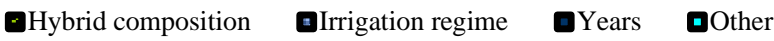

Fig. 1 Distribution of the influence of the studied factors on grain productivity of the hybrids of different FAO groups, \% 
The study of the genotypic variability of the hybrid composition under different irrigation regimes and in different moisture conditions showed that the optimum irrigation regime showed the greatest variability $(\mathrm{R}=4.05$ $6.45 \mathrm{t} / \mathrm{ha}$ ). The range of genotypic yields at the water-saving regime and without irrigation was significantly inferior (Table 2).

However, the coefficient of genotypic variability $\left(\mathrm{V}_{\mathrm{g}}, \%\right)$ increased significantly with the deterioration of cultivation conditions. This phenomenon is somewhat counterintuitive and contradicts the theory of "environmental permitting capacity", which testifies about opening of genotype potential under optimal technological measures ${ }^{5,6,7}$.

However, if we trace back to the analysis of the previous experimental data (see Table 1), we can see the reason for such a critical increase in genotypic variability with deterioration of water supply. This was due to a change in the ranking of the hybrids and a critical decline in the yield of lateripening hybrids.

The most potentially productive hybrids (Borysfen 600SV, Borysfen $433 \mathrm{MV}$ ) produced twice less yield without irrigation than the fast-ripening ones. This has led to a misleading increase in the coefficient of genotypic variability.

In favorable by weather conditions years the genotype differences in yields and the coefficient of variation have also slightly decreased. Thus, the statistical indices of the genotypic diversity of corn can be distorted by stressful environmental conditions, so hybrids must be compared by absolute values in the relevant agro-ecological gradients.

The study of the modifying effect of irrigation regime in different weather conditions showed that in favorable weather conditions the coefficients of paratypical variability were significantly less in comparison to the drier (moderate and moderately dry) years (Table 3).

This phenomenon is quite predictable, since the irrigation regime in the conditions of southern arid Steppe is a major factor in the formation of high yields. It is also noteworthy that the coefficients of variation increased in parallel with the increase in the duration of the vegetation period of hybrids (up to $82 \%$ ), which is a confirmation of the high sensitivity of late-ripening hybrids to drought. Hybrids with FAO 190-300 were the least sensitive to weather conditions and irrigation regime.

${ }^{5}$ Eberhart S.A., Russell W.A. Stability parameters for comparing varieties. Crop Sci. 1966. Vol. 6, N 1. P. 36-40.

${ }_{6}^{6}$ Кильчевский А.В., Хотылева Л.В. Метод оценки адаптивной способности и стабильности генотипов, дифференцирующей способности среды. Генетика. 1985. Т. XXI, № 9. С. 1481-1497.

7 Черчель В.Ю., Антонюк С.П., Олешко А.А., Дуда А.Н. Селекция скороспелых гибридов для Степи Украины. Бюлетень Інституту зернового господарства. 1997. № 3(5). C. 7-9. 
Table 2

Genotype variability in the yields of hybrids depending on different years and at different irrigation regimes

\begin{tabular}{|l|c|c|c|c|}
\hline \multirow{2}{*}{ Years } & \multirow{2}{*}{$\begin{array}{c}\text { Statistical } \\
\text { indices }\end{array}$} & \multicolumn{3}{|c|}{ Irrigation regimes } \\
\cline { 3 - 5 } & & Optimal & $\begin{array}{c}\text { Water- } \\
\text { saving }\end{array}$ & $\begin{array}{c}\text { Without } \\
\text { irrigation }\end{array}$ \\
\hline \multirow{3}{*}{ Humid } & $\mathrm{x}, \mathrm{t} / \mathrm{ha}$ & 11.33 & 9.70 & 4.42 \\
\cline { 2 - 5 } & $\mathrm{R}, \mathrm{t} / \mathrm{ha}$ & 4.05 & 2.18 & 2.23 \\
\cline { 2 - 5 } & $\mathrm{V}_{\mathrm{g}}, \%$ & 10.66 & 6.31 & 18.84 \\
\hline \multirow{3}{*}{ Moderate } & $\mathrm{x}, \mathrm{t} / \mathrm{ha}$ & 10.67 & 8.80 & 3.12 \\
\cline { 2 - 5 } & $\mathrm{R}, \mathrm{t} / \mathrm{ha}$ & 5.86 & 4.00 & 2.73 \\
\cline { 2 - 5 } & $\mathrm{V}_{\mathrm{g}}, \%$ & 15.85 & 15.13 & 27.14 \\
\hline \multirow{3}{*}{ Moderately dry } & $\mathrm{x}, \mathrm{t} / \mathrm{ha}$ & 10.34 & 8.66 & 2.83 \\
\cline { 2 - 5 } & $\mathrm{R}, \mathrm{t} / \mathrm{ha}$ & 6.45 & 3.84 & 2.14 \\
\cline { 2 - 5 } & $\mathrm{V}_{\mathrm{g}}, \%$ & 18.03 & 15.92 & 24.09 \\
\hline
\end{tabular}

Table 3

Modification variability $\left(\mathrm{V}_{\mathrm{m}}, \%\right)$ of the hybrids' yields depending on the influence of modification activity of irrigation regime in different years

\begin{tabular}{|l|c|c|c|}
\hline \multirow{2}{*}{\multicolumn{1}{|c|}{ Hybrids }} & \multicolumn{3}{c|}{ Years } \\
\cline { 2 - 4 } & Humid & Moderate & Moderately dry \\
\hline Tendra & $29 . .42$ & $40 . .04$ & $42 . .31$ \\
\hline Borysfen 191MV & $37 . .66$ & $34 . .84$ & $36 . .87$ \\
\hline Borysfen 250MV & $38 . .42$ & $46 . .64$ & $48 . .82$ \\
\hline Syvash & $31 . .92$ & $43 . .91$ & $49 . .97$ \\
\hline Borysfen 380MV & $45 . .94$ & $50 . .91$ & $53 . .24$ \\
\hline Azov & $51 . .31$ & $59 . .69$ & $57 . .48$ \\
\hline Borysfen 433MV & $52 . .61$ & $61 . .55$ & $63 . .21$ \\
\hline Borysfen 600SV & $59 . .10$ & $79 . .48$ & $82 . .15$ \\
\hline
\end{tabular}

The study of the modifying effect of the weather conditions of a year at certain irrigation regimes showed that the optimal regime and water almost offset the effects of extreme weather factors (Table 4).

The absence of irrigation greatly increases the variability of the yield depending on the effects of weather conditions, and in late hybrids (Borysfen $600 \mathrm{SV}$ ), the weather conditions are almost equal to the effect of the irrigation factor by the impact. Thus, late-ripening corn hybrids are particularly demanding to irrigation regime and can increase yield unpredictability under the extreme weather conditions during the vegetation period. The hybrids of the middle-early and middle-ripening groups are more stable.

Thus, in dry weather conditions, the yield level of late hybrids may not be reduced adequately to genotype potential. This leads to the fact that the 
selection of high-yielding hybrids with FAO exceeding 400 in dry weather conditions may not be effective, and the most productive group is FAO 280-390, which due to the plasticity and less water consumption in such years provides the highest grain yield.

Table 4

Modification variability $\left(\mathrm{V}_{\mathrm{m}}, \%\right)$ of the hybrids' yields depending on the effect of weather conditions of a year at different irrigation regimes

\begin{tabular}{|l|c|c|c|}
\hline \multirow{2}{*}{\multicolumn{1}{|c|}{ Hybrids }} & \multicolumn{3}{|c|}{ Irrigation regimes } \\
\cline { 2 - 4 } & Optimal & Water-saving & Without irrigation \\
\hline Tendra & 6.95 & 9.94 & 25.97 \\
\hline Borysfen 191MV & 19.49 & 29.79 & 19.60 \\
\hline Borysfen 250MB & 3.20 & 4.89 & 19.41 \\
\hline Syvash & 2.14 & 1.77 & 27.16 \\
\hline Borysfen 380MB & 2.07 & 2.24 & 13.53 \\
\hline A30B & 9.43 & 2.21 & 21.28 \\
\hline Borysfen 433MB & 1.14 & 1.15 & 22.71 \\
\hline Borysfen 600CB & 2.17 & 7.83 & 61.33 \\
\hline
\end{tabular}

\section{Adaptability of hybrids by grain yield in the conditions of southern Steppe}

An important question for crop production is the selection of genotypes with a specific response to technological support and soil-climatic conditions. Under controlled environmental conditions, it is advisable to select for the specific adaptive capacity (SAC). Hybrids of the middleripening, middle-late and late-ripening groups showed high SAC, that is, all of them are capable of increasing the yield while improving cultivation conditions (Table 5). The relative stability of the reaction prediction is also inherent in these hybrids.

The coefficient of plasticity $\left(b_{i}\right)$ is the most informative index of genotype's reaction on the changes of environmental conditions. The hybrids are divided into the groups by the coefficient of plasticity:

1. Homeostatic $\left(b_{i}<1\right)$ - hybrids, which are characterized by a weak response to changes in cultivation conditions and providing stable yields under deteriorating conditions. This group includes early maturing hybrids Tendra and Borysfen 191MV.

2. Intensive type $\left(b_{i}>1\right)$ - high-plastic hybrids with high genetic potential, but with low stability in yields. This group includes middle and late hybrids Azov, Borysfen 433MV, Borysfen 600SV. These hybrids have a very high yielding potential (over $14 \mathrm{t} / \mathrm{ha}$ ), but require careful and timely execution of technological operations. Disruptions in technology, or weather extremeties, dramatically reduce yields, sometimes to a complete loss. 
For the simultaneous selection for the overall adaptive capacity and stability, the index of "genotype breeding value" (GBV) is used. The highest breeding value under these conditions was shown by Syvash hybrid, which showed a rather stable grain yield in different ecological gradients. Hybrids of this type can produce maximum yields even in unfavorable conditions.

Overall adaptive capacity (OAC), an index that combines all previous parameters, also reached the highest values in Syvash hybrid, which emphasizes its prospect for tyhe use in these agro-economic conditions.

To improve the plant breeding theory, determining the environment as the background for plant breeding is of great importance. It is generally accepted to divide the background into a stabilizing one, in which the genotypic polymorphism of the population is narrowed by stabilizing factors; analyzing one, which contributes to the phenotypic manifestation of genotypic inclinations; leveling one, at which the differences between genotypes are minimized ${ }^{8}$. Researchers are usually attracted by the analyzeingbreeding background. To assess the environment as a background for plant breeding, use the indicator DCE (differentiating capacity of the environment). In our experiments, the DCE reached the highest values under the optimal irrigation regime (Table 5).

Table 5

Evaluating environment as a background for plant breeding

\begin{tabular}{|c|c|c|c|c|}
\hline $\begin{array}{c}\text { Ecological } \\
\text { gradient } \\
\text { No. }\end{array}$ & $\begin{array}{c}\text { DCE } \\
\text { (differentiating } \\
\text { capacity of the } \\
\text { environment) }\end{array}$ & $\begin{array}{c}\text { Variance of the } \\
\text { interaction gene } \times \\
\text { environment }\end{array}$ & $\begin{array}{c}\text { Predictability } \\
\text { index }\end{array}$ & Background \\
\hline 1 & 166.6 & 124.1 & 0.05 & Stabilizing \\
\hline 2 & 326.9 & 190.4 & 0.12 & Analyzing \\
\hline 3 & 396.8 & 243.5 & 0.14 & Analyzing \\
\hline 4 & 42.8 & 63.7 & 0.02 & Stabilizing \\
\hline 5 & 202.7 & 63.2 & 0.15 & Analyzing \\
\hline 6 & 217.0 & 80.7 & 0.15 & Analyzing \\
\hline 7 & 80.0 & 128.2 & 0.001 & Leveling \\
\hline 8 & 81.7 & 134.1 & -0.001 & Leveling \\
\hline 9 & 52.9 & 103.2 & -0.004 & Leveling \\
\hline
\end{tabular}

The genotype $\times$ environment interaction variance reahed the highest value in the dry years at the optimal irrigation regime (gradients number 2, 3) Also, significant interaction between genotype and ecological gradient was observed in the non-irrigated variants.

8 Козубенко Л.В., Гурьева И.А. Селекция кукурузы на раннеспелость. Харьков, 2002. $239 \mathrm{c}$. 
However, the predictability was positive for dry land only in humid years (gradient number 7), and in drought conditions the predictability was negative, indicating a change in the ranking of the hybrids in the rainfed conditions.

The reaction of the hybrids to agrotechnical measures is reflected in the Fig. 2. At the ecological gradient that provides yields at the level of 6-8 t/ha, the potential of most hybrids is at the verge of opening. Optimization of the agricultural background results in higher yields exceeding $12 \mathrm{t} / \mathrm{ha}$ in the hybrids with genotypical high-yielding inclinations and their separation from homeostatic ones. When the background is lower than $5 \mathrm{t} / \mathrm{ha}$, the ranking of the hybrids changes, which can lead to mistaken conclusions during the selection of high-yielding hybrids.

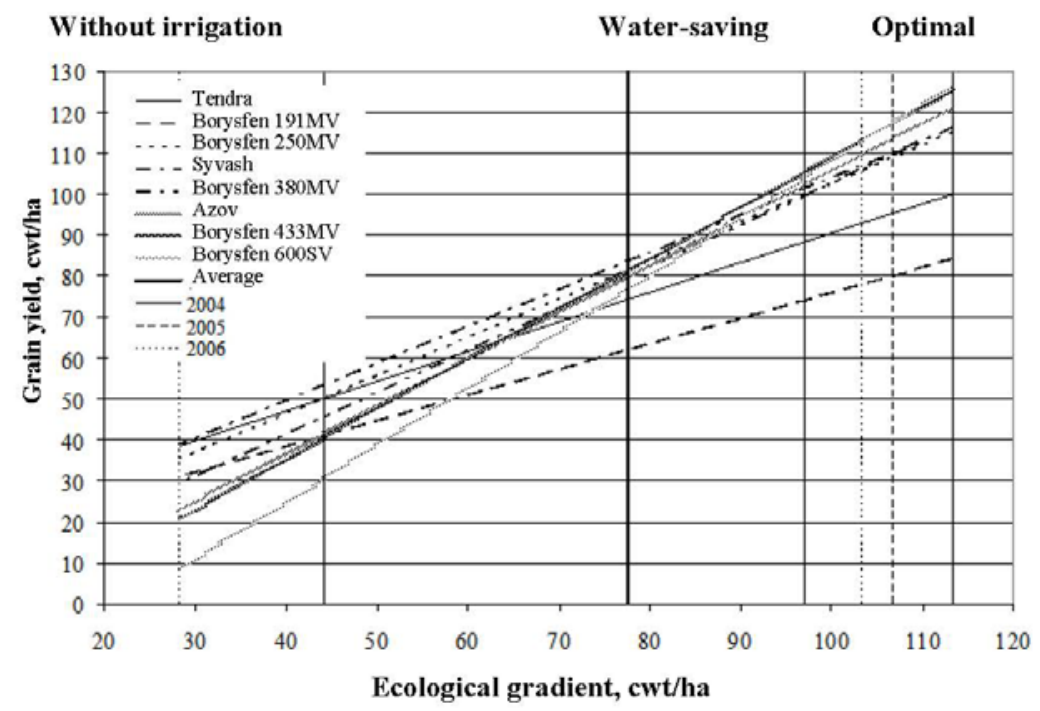

Fig. 2 Regression lines for the index of environmental conditions by the yields of corn hybrids

Thus, the most favorable backgrounds for the selection of corn hybrids of certain ripeness groups and predictable response to technological support are the conditions of the optimal irrigation regime in the years, which are characterized by average (typical) indices of rainfall and air temperature during the vegetation period.

Homeostatic hybrids have been identified, which are characterized by a weak response to the changes in cultivation conditions and provide stable yields under worsening conditions. This group includes early ripening hybrids 
Tendra and Borysfen 191MV. Highly plastic hybrids (Azov, Borysfen $433 \mathrm{MV}$, Borysfen 600SV) have been determined as ones owing high genetic potential, but with low stability of yield, that requires careful and timely performance of technological operations. Disruptions of technology or weather extremities critically reduce their productivity.

The most versatile are moderately plastic middle-early hybrids, which use the autumn-winter moisture reserves quite efficiently, have an adequate response to the improvement of cultivation conditions, and are characterized by a restrained response to adverse weather fluctuations and fluctuations in agriculture level. Such hybrids include Syvash hybrid.

\section{Manifestation of plants height of corn hybrids depending on irrigation regime}

The height of corn plants has received much attention in research because it is closely linked to overall adaptive capacity and potential productivity ${ }^{9}$. Plant height can be a side indicator of total biomass yield, photosynthetic potential, and its less variability in the years of insufficient humidification can be considered as a higher resistance of an individual hybrid to unfavorable conditions, and especially to drought ${ }^{10,11}$.

Analysis of plant height of corn hybrids showed that this index increased with the elongation of the vegetation period (Table 6). The highest, on average by years, was the late-ripening Borysfen 600SV hybrid. The fastripening hybrids had the lowest height of $226 \mathrm{~cm}$, while others occupied an intermediate position.

Weather conditions of the year had a certain influence on the manifestation of the features, as it is evidenced by the decrease in the plant height in the dry years. The most critical decrease in the indices of this feature was observed in the variants without irrigation.

If the decrease in plant height with water-saving irrigation regime was limited to 13-16 cm in hybrids Borysfen 380MV, Borysfen 433MV, Borysfen $600 \mathrm{SV}$, then without irrigation, the later ripening hybrids critically reduced the height of the plants in unfavorable weather conditions by $30-33 \mathrm{~cm}$. The reaction of the hybrids with FAO 190-300 was more restrained, indicating their increased adaptability to drought.

\footnotetext{
${ }^{9}$ Нетреба О.О., Лавриненко Ю.О. Успадкування та мінливість ознаки «висота рослин» у гібридів кукурудзи різних поколінь самозапилення, створених на базі ліній, контрастних за довжиною вегетаційного періоду. Зрошуване землеробство. 2005. Вип. 44. С. 99-102.

10 Домашнев П.П., Дзюбецкий Б.В., Костюченко В.И. Селекция кукурузы. Тр. ВАСХНИЛ. Москва: Агропромиздат, 1992. С. 11.

${ }^{11}$ Мазур О.В. Селекційний матеріал для створення гібридів кукурудзи, придатних до механізованого обмолоту: автореф. дис. ... к-та с.-г.наук: 06.01.05. Київ: Інститут землеробства УААН, 2005. 19 с.
} 
Table 6

Effect of irrigation regimes on the plants' height of different ripeness groups of corn by the years of the study, $\mathrm{cm}$

\begin{tabular}{|c|c|c|c|c|c|c|}
\hline \multirow[b]{2}{*}{$\begin{array}{c}\text { Hybrid } \\
\text { (Factor A) }\end{array}$} & \multirow[b]{2}{*}{$\begin{array}{c}\text { Irrigation } \\
\text { regime (Factor B) }\end{array}$} & \multicolumn{4}{|c|}{ Years } & \multirow[b]{2}{*}{ 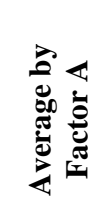 } \\
\hline & & 畐 & & 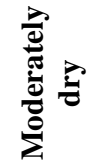 & 范 & \\
\hline \multirow{3}{*}{ Tendra } & Without irrigation & 218.8 & 217.3 & 214.8 & 217.0 & \multirow{3}{*}{226,0} \\
\hline & Water-saving & 230.5 & 227.5 & 224.5 & 227.5 & \\
\hline & Optimal & 236.8 & 233.8 & 230.0 & 233.5 & \\
\hline \multirow{3}{*}{$\begin{array}{l}\text { Borysfen } \\
\text { 191MV }\end{array}$} & Without irrigation & 216.8 & 216.3 & 214.8 & 216.0 & \multirow{3}{*}{226,7} \\
\hline & Water-saving & 230.8 & 229.0 & 227.8 & 229.2 & \\
\hline & Optimal & 236.3 & 235.3 & 233.5 & 235.0 & \\
\hline \multirow{3}{*}{$\begin{array}{l}\text { Borysfen } \\
250 \mathrm{MV}\end{array}$} & Without irrigation & 223.8 & 222.0 & 221.0 & 222.3 & \multirow{3}{*}{234,0} \\
\hline & Water-saving & 238.0 & 236.0 & 234.8 & 236.3 & \\
\hline & Optimal & 245.8 & 244.5 & 240.0 & 243.4 & \\
\hline \multirow{3}{*}{ Syvash } & Without irrigation & 233.3 & 222.8 & 222.5 & 226.2 & \multirow{3}{*}{239,1} \\
\hline & Water-saving & 242.8 & 238.5 & 236.3 & 239.2 & \\
\hline & Optimal & 266.0 & 246.3 & 243.0 & 251.8 & \\
\hline \multirow{3}{*}{$\begin{array}{l}\text { Borysfen } \\
380 \mathrm{MV}\end{array}$} & Without irrigation & 249.8 & 219.0 & 216.3 & 228.4 & \multirow{3}{*}{243,0} \\
\hline & Water-saving & 253.0 & 244.3 & 240.5 & 245.9 & \\
\hline & Optimal & 256.8 & 255.3 & 252.0 & 254.7 & \\
\hline \multirow{3}{*}{ Azov } & Without irrigation & 238.5 & 223.0 & 219.0 & 226.8 & \multirow{3}{*}{248,8} \\
\hline & Water-saving & 251.5 & 246.0 & 240.5 & 246.0 & \\
\hline & Optimal & 280.3 & 272.3 & 268.0 & 273.5 & \\
\hline \multirow{3}{*}{$\begin{array}{l}\text { Borysfen } \\
\text { 433MV }\end{array}$} & Without irrigation & 234.3 & 223.5 & 218.0 & 225.3 & \multirow{3}{*}{248,3} \\
\hline & Water-saving & 259.8 & 249.0 & 245.8 & 251.5 & \\
\hline & Optimal & 278.8 & 265.3 & 260.3 & 268.1 & \\
\hline \multirow{3}{*}{$\begin{array}{l}\text { Borysfen } \\
600 S V\end{array}$} & Without irrigation & 226.3 & 217.5 & 196.5 & 213.4 & \multirow{3}{*}{259,9} \\
\hline & Water-saving & 279.8 & 273.3 & 263.8 & 272.3 & \\
\hline & Optimal & 302.8 & 294.0 & 285.0 & 293.9 & \\
\hline \multicolumn{7}{|c|}{ A. Evaluation of the significance of partial differences: } \\
\hline \multirow{2}{*}{$\mathrm{LSD}_{05}$} & $A=$ & \multicolumn{5}{|c|}{8.8} \\
\hline & $\mathrm{B}=$ & \multicolumn{5}{|c|}{8.1} \\
\hline \multicolumn{7}{|c|}{ B. Evaluation of the significance of means (main effects): } \\
\hline \multirow{2}{*}{$\mathrm{LSD}_{05}$} & $\mathrm{~A}=$ & \multicolumn{5}{|c|}{5.1} \\
\hline & $\mathrm{B}=$ & \multicolumn{5}{|c|}{3.1} \\
\hline
\end{tabular}


The hybrid composition and irrigation regime had a much greater effect on the height of corn plants (Fig. 3). Analyzing the obtained experimental data, we can observe that the share of hybrids in the formation of plant height was the highest in favorable wet by the weather conditions years and was $37 \%$.
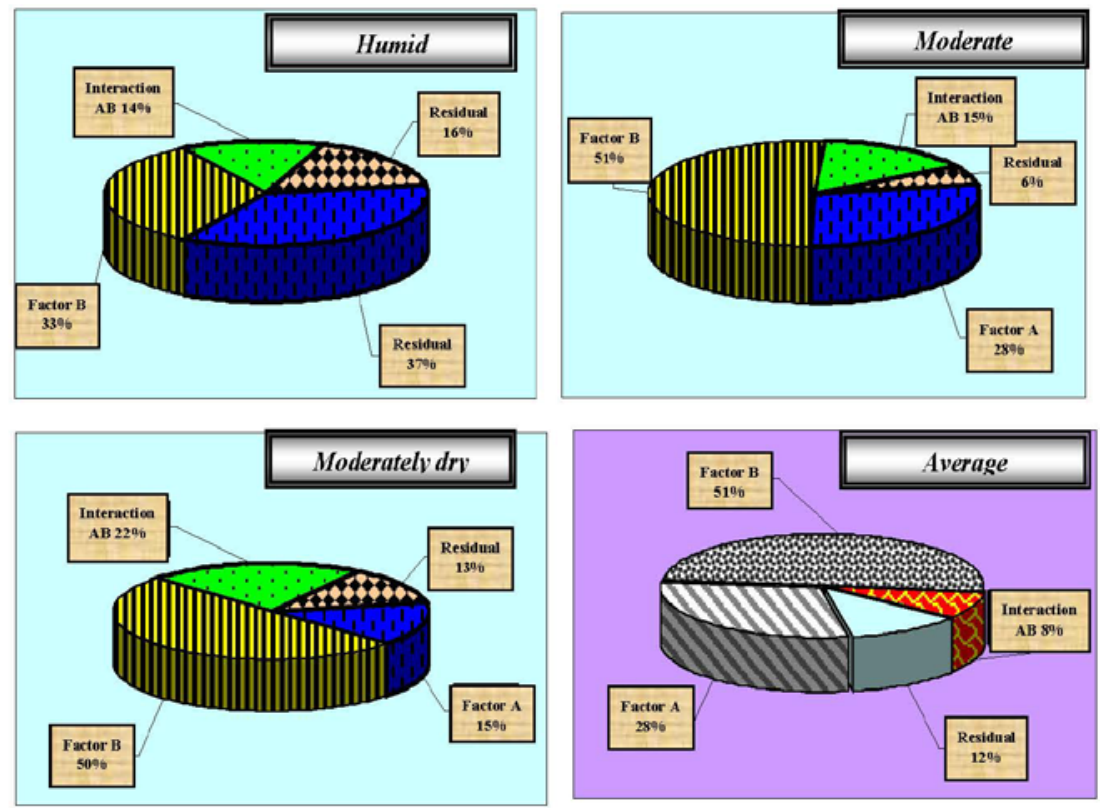

Fig. 3 Share of the hybrid composition (Factor A) and irrigation regime (Factor B) in the formation of the height of corn plants in the years of the study, \%

Irrigation regimes this year affected the height of the plants little less $33 \%$. However, in subsequent, drier years, the irrigation regime (50-51\%) was the undisputed major factor in the formation of plant height.

The interaction of irrigation regimes and genotype was most significant in the dry years and reached $22 \%$. This indicates that the features of plant height formation are inherent for individual corn genotypes, and they will be completely determined by the irrigation conditions in severe weather conditions, and the genotype factor may be reduced from 37 to 15\%. On average, by the years of the research, the water supply of corn crops determined the formation of plant height by more than a half and the impact of hybrid composition - by $29 \%$. 
By the results of the analysis of variances it was found that the least environmental variability was observed in the fast-ripening hybrids (3.4, 4.3\%) as well as in the middle-early ones (Table 7).

Table 7

Results of the analysis of variances of variability of the plants height depending on the hybrid composition and irrigation regime, $\mathrm{cm}$

\begin{tabular}{|c|c|c|c|c|c|}
\hline \multirow{3}{*}{$\begin{array}{c}\text { Variants of the } \\
\text { experiment }\end{array}$} & \multicolumn{5}{|c|}{ Indices of the analysis of variance } \\
\hline & \multirow{2}{*}{$\bar{x}$} & \multirow{2}{*}{$s_{X}$} & \multirow{2}{*}{$\mathrm{V}, \%$} & \multicolumn{2}{|c|}{ Lim } \\
\hline & & & & $\min$ & $\max$ \\
\hline \multicolumn{6}{|c|}{ Hybrid composition (Factor A) } \\
\hline Tendra & 226.0 & 4.8 & 3.4 & 210.7 & 241.3 \\
\hline Borysfen 191MV & 226.7 & 5.6 & 4.3 & 208.8 & 244.6 \\
\hline Borysfen 250MV & 234.0 & 6.2 & 4.6 & 214.3 & 253.7 \\
\hline Syvash & 239.1 & 7.4 & 5.4 & 215.6 & 262.6 \\
\hline Borysfen 380MV & 243.0 & 7.7 & 5.5 & 218.4 & 267.6 \\
\hline Azov & 248.8 & 13.6 & 9.4 & 205.6 & 291.9 \\
\hline Borysfen 433MV & 248.3 & 12.5 & 8.7 & 208.7 & 287.9 \\
\hline Borysfen 600SV & 259.9 & 24.1 & 16.0 & 183.3 & 336.4 \\
\hline \multicolumn{6}{|c|}{ Irrigation regime (Factor $B$ ) } \\
\hline Without irrigation & 221.9 & 2.0 & 2.6 & 217.3 & 226.6 \\
\hline Water-saving & 243.5 & 5.1 & 5.9 & 231.8 & 255.2 \\
\hline Optimal & 256.7 & 7.3 & 8.1 & 239.8 & 273.6 \\
\hline
\end{tabular}

The steep increase in the coefficient of variation of up to $16 \%$ in the late-ripening Borysfen 600SV hybrid testifies about a high instability of manifestation of the feature. The moderate variability of the plant height was demonstrated by hybrids of the middle-late group Azov and Borysfen 433MV. It should be mentioned that the same variability was also fixed in the yield of these hybrids, so it is possible to predict under some circumstances the level of instability of the grain yield of corn hybrids by the variability of plant height.

Thus, the height of plants of corn hybrids in the conditions of southern Steppe is determined mainly by the conditions of moisture supply. The prevailing influence of the hybrid on the plant height is manifested under the conditions of optimal irrigation regime and favorable weather conditions by the years. Variability of the height of the plants of a hybrid depending on weather conditions of a year and conditions of humidification can be used as the express method of determination of stability of manifestation of grain yield. 


\section{Manifestation of cob setting in corn hybrids depending on irrigation regime and weather conditions}

The use of energy-saving corn cultivation technologies has specific requirements to the habitat of hybrids. One among them is the ability to be mechanically harvested through direct threshing in the field. Plants with medium height of 2.0-2.5 meters with a height of the top productive cob setting at least at $50 \mathrm{~cm}$ from the soil level are the most suitable for mechanical harvesting ${ }^{12}$.

The height of the cob setting is positively correlated with the plant resistance to lodging and the synchrony of flowering in different ripening groups of corn. These are important factors at the use of intensive cultivation technologies. In addition, this feature is one of the main factors affecting the yield of grain, which in its turn determines the potential and actual yield of a particular variety ${ }^{13}$.

In the complex of physiological and morphological features that provide adaptation in the conditions of intensive agriculture, an important role belongs to the architectonics of plants. The height of the cob setting is one of the important features that determine the adaptability to modern intensive technologies for cultivation corn hybrids ${ }^{14}$.

In our studies, the height of the cob setting was quite variable. Unfavorable dry conditions of the year significantly reduced the height of the cob, even in the conditions of optimal moisture supply (Table 8). Particularly noticeable decrease was observed in the middle-late and late-ripening hybrids (by 20-24 cm). An even more drastic decrease in the height of the cob setting was caused by the water supply restriction. Thus, in the late and middle-late hybrids (Borysfen 600SV, Borysfen 433MV), the height of the cob setting was reduced in the variants without irrigation by more than two times compared to the optimal irrigation regime. Early and late ripening hybrids in the dry years showed the same negative adaptive reaction and had plant architectonics that did not meet the requirements of harvesting (below $50 \mathrm{~cm}$ ).

It should be mentioned that the height of the cob setting, on average by the factor $\mathrm{A}$, had a positive relationship with the duration of the vegetation period of the hybrids, but this relationship was completely absent in the variants without irrigation. Therefore, the true habitat of plants can only be determined under the conditions of optimal irrigation regime.

12 Лавриненко Ю.О., Плоткін С.Я. Мінливість кореляційної залежності адаптивних ознак у гібридів кукурудзи залежно від груп стиглості. Таврійський науковий вісник. 2005. Вип. 38. С. 17-23.

${ }^{13}$ Vera G.A., Crane P.L. Effects of selection for lover ear height in synthetic populations of maize. Crop Sci. 1970. № 10. P. 286-288.

14 Мартиненко О.І. Ріст і адаптація рослин: кількісний підхід. Селекція і генетика в Україні на межі тисячоліть. Київ: Логос, 2001. Том 2. С. 115-122. 
Table 8

The influence of irrigation regimes on the height of the cob setting in different hybrids of corn by the years of the research, $\mathrm{cm}$

\begin{tabular}{|c|c|c|c|c|c|c|}
\hline \multirow[b]{2}{*}{$\begin{array}{c}\text { Hybrid } \\
\text { (Factor A) }\end{array}$} & \multirow[b]{2}{*}{$\begin{array}{l}\text { Irrigation regime } \\
\text { (Factor B) }\end{array}$} & \multicolumn{4}{|c|}{ Years } & \multirow[b]{2}{*}{$\begin{array}{l}\text { Average } \\
\text { by the } \\
\text { Factor A }\end{array}$} \\
\hline & & 吾 & & 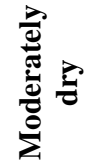 & 范 & \\
\hline \multirow{3}{*}{ Tendra } & Without irrigation & 48.8 & 48.5 & 40.8 & 46.0 & \multirow{3}{*}{55.0} \\
\hline & Water-saving & 60.5 & 58.5 & 50.5 & 56.5 & \\
\hline & Optimal & 66.8 & 64.8 & 56.0 & 62.5 & \\
\hline \multirow{3}{*}{$\begin{array}{l}\text { Borysfen } \\
\text { 191MV }\end{array}$} & Without irrigation & 46.8 & 44.3 & 40.8 & 44.0 & \multirow{3}{*}{55.0} \\
\hline & Water-saving & 60.8 & 58.8 & 53.8 & 57.8 & \\
\hline & Optimal & 66.3 & 64.3 & 59.5 & 63.4 & \\
\hline \multirow{3}{*}{$\begin{array}{l}\text { Borysfen } \\
250 \mathrm{MV}\end{array}$} & Without irrigation & 53.8 & 51.8 & 47.0 & 50.9 & \multirow{3}{*}{62.6} \\
\hline & Water-saving & 68.0 & 66.0 & 60.8 & 64.9 & \\
\hline & Optimal & 75.8 & 73.8 & 66.0 & 71.9 & \\
\hline \multirow{3}{*}{ Syvash } & Without irrigation & 63.3 & 59.8 & 48.5 & 57.2 & \multirow{3}{*}{67.4} \\
\hline & Water-saving & 72.8 & 70.8 & 62.3 & 68.6 & \\
\hline & Optimal & 81.0 & 79.0 & 69.0 & 76.3 & \\
\hline \multirow{3}{*}{$\begin{array}{l}\text { Borysfen } \\
\text { 380MV }\end{array}$} & Without irrigation & 79.8 & 57.3 & 42.3 & 59.8 & \multirow{3}{*}{73.3} \\
\hline & Water-saving & 83.0 & 81.0 & 66.5 & 76.8 & \\
\hline & Optimal & 86.8 & 84.8 & 78.0 & 83.2 & \\
\hline \multirow{3}{*}{ Azov } & Without irrigation & 68.5 & 57.5 & 45.0 & 57.0 & \multirow{3}{*}{78.7} \\
\hline & Water-saving & 81.5 & 79.5 & 66.5 & 75.8 & \\
\hline & Optimal & 110.3 & 105.3 & 94.0 & 103.2 & \\
\hline \multirow{3}{*}{$\begin{array}{l}\text { Borysfen } \\
\text { 433MV }\end{array}$} & Without irrigation & 64.3 & 57.3 & 44.0 & 55.2 & \multirow{3}{*}{79.3} \\
\hline & Water-saving & 89.8 & 86.3 & 71.8 & 82.6 & \\
\hline & Optimal & 108.8 & 104.8 & 86.3 & 100.0 & \\
\hline \multirow{3}{*}{$\begin{array}{l}\text { Borysfen } \\
\text { 600SV }\end{array}$} & Without irrigation & 56.3 & 52.8 & 40.5 & 49.9 & \multirow{3}{*}{89.9} \\
\hline & Water-saving & 109.8 & 104.3 & 89.8 & 101.3 & \\
\hline & Optimal & 132.8 & 113.8 & 109.0 & 118.5 & \\
\hline \multicolumn{7}{|c|}{ A. Evaluation of the significance of partial effects: } \\
\hline \multirow{2}{*}{$\mathrm{LSD}_{05}$} & $\mathrm{~A}=$ & \multicolumn{5}{|c|}{9.2} \\
\hline & $\mathrm{B}=$ & \multicolumn{5}{|c|}{8.1} \\
\hline \multicolumn{7}{|c|}{ B. Evaluation of significance of the means (main effects): } \\
\hline \multirow{2}{*}{$\mathrm{LSD}_{05}$} & $\mathrm{~A}=$ & \multirow{2}{*}{\multicolumn{5}{|c|}{$\begin{array}{r}5.3 \\
3.1\end{array}$}} \\
\hline & $\mathrm{B}=$ & & & & & \\
\hline
\end{tabular}

The weather conditions of the year had a considerable influence on the proportion of participation of individual factors on the height of the cob setting. If, under favorable weather conditions, the proportion of factor A (hybrids) was dominant (41\%), then with the worsening of the weather, the impact rate decreased to $22 \%$. At the same time, the influence of factor B 
(irrigation regime) increased from 32 to $51 \%$. On average, by the years of the research, the regime of irrigation (46\%) had stronger effect on the height of the cob setting.

Under the determination of the indices of variability in the height of the cob setting, it was found that this feature has medium and high coefficients of variation (Table 9).

Table 9

Results of analysis of variance of the variability of the height of the cob setting depending on the hybrid composition and irrigation regime, $\mathrm{cm}$

\begin{tabular}{|l|c|c|c|c|c|}
\hline \multirow{2}{*}{$\begin{array}{c}\text { Variants of the } \\
\text { experiment }\end{array}$} & $\overline{5}$ Indices of the analysis of variance \\
\cline { 2 - 6 } & $\bar{x}$ & $\boldsymbol{s}_{\boldsymbol{x}}$ & \multirow{2}{*}{ V, \% } & \multicolumn{2}{c|}{ Lim } \\
\cline { 3 - 6 } & & & $\mathbf{m i n}$ & $\mathbf{m a x}$ \\
\hline Tendra & 55.0 & 4.82 & 15.2 & 39.7 & 70.3 \\
\hline Borysfen 191MV & 55.1 & 5.8 & 18.1 & 36.7 & 73.4 \\
\hline Borysfen 250MV & 62.6 & 6.2 & 17.1 & 42.9 & 82.2 \\
\hline Syvash & 67.4 & 5.6 & 14.3 & 49.7 & 85.0 \\
\hline Borysfen 380MV & 73.3 & 7.0 & 16.5 & 51.0 & 95.5 \\
\hline Azov & 78.7 & 13.4 & 29.5 & 36.0 & 121.3 \\
\hline Borysfen 433MV & 79.3 & 13.0 & 28.5 & 37.8 & 120.8 \\
\hline Borysfen 600SV & 89.9 & 20.6 & 39.7 & 24.3 & 155.5 \\
\hline & Irrigation regime (Factor B) & & \\
\hline Without irrigation & 52.5 & 2.0 & 10.8 & 47.9 & 57.1 \\
\hline Water-saving & 73.0 & 5.2 & 20.1 & 61.1 & 85.0 \\
\hline Optimal & 84.9 & 7.2 & 24.0 & 68.3 & 101.5 \\
\hline
\end{tabular}

The increase in the coefficient of variation from early to late-ripening hybrids was remarkable and reached $39.7 \%$ in Borysfen 600SV hybrid. Although the average index for this hybrid was the largest $(89.9 \mathrm{~cm})$, the confidence interval overlapped all possible variants of the previous hybrids, which did not give a high predictability of comparing significant differences with other hybrids. However, such high variability and unpredictability were observed at all moisture levels, which do not interfere with provision of more detailed and reliable evaluation of hybrids under the optimal irrigation regime. Confirmation of this is the indices of variability of hybrids under different humidification conditions.

Under the optimal irrigation regime, the coefficient of variation of the hybrid composition exceeded the variant without irrigation by more than 2 times (24\%). This provides pre-conditions for an objective assessment of the potential of hybrids only under the conditions of the optimal cultivation technology. The disruption of technology or the effects of extreme weather 
conditions of the year can significantly mask the potential of corn hybrids, alter the correlation or even change their direction, and in general, create additional barriers to identifying the most promising hybrids by manifestation of phenotypic features.

\section{CONCLUSIONS}

1. It is advisable to cultivate hybrids with FAO not exceeding 300 at energy-saving technologies and rain-fed conditions in southern Steppe subzone. Such hybrids include Borysfen 250MV and Syvash (grain yields of 8.1-8.4 t/ha). More fast-ripening hybrids should be used at water-saving technologies and on rain-fed lands as previous crops for winter crops (yield 6.2-7.4 t/ha). The hybrids with FAO exceeding 350 should be used at the optimal irrigation and mineral nutrition because their yields have significant advantages over the earlier ripening genotypes only under the mentioned technologies (yield 12.1-13.3 t/ha).

2. In dry weather conditions, the yield level of late hybrids may not be adequate to genotype potential. This leads to the fact that identifying and opening the potency of high-yielding hybrids with FAO exceeding 400 in dry weather may not be effective, but the most productive is the FAO group of 280-390, which, due to its plasticity and less water consumption, provides the highest grain yield in such years. Hybrids with FAO exceeding 500 have a high yield potential, however, the strong negative response of these genotypes to environmental fluctuations results in a decrease in the yield below the level of earlier ripening hybrids and places them outside the group of hybrids, which are suitable for efficient use in southern Steppe in the irrigated conditions at current stage of development of agriculture.

3. The absence of irrigation greatly increases the variability in yield from the influence of weather conditions, and in late-ripening hybrids (Borysfen 600SV), the impact of weather conditions is almost equal to the effect of the irrigation factor. The plasticity factor $\left(b_{i}\right)$ is the most informative index of the genotypes response to the changes in cultivation technology and weather conditions. The most favorable backgrounds for plant breeding of the best corn hybrids of certain ripening groups and predictability of technological support are the conditions of the optimal irrigation regime in the years, which are characterized by average (typical) indices of rainfall and air temperature during the vegetation period.

\section{SUMMARY}

The article presents the results of the studies on the effect of hydrothermal conditions on the productivity of corn hybrids of different ripening groups. It has been established that the fast ripening hybrids should be used at the water-saving technologies and on the rain-fed land as previous 
crops for winter crops (yield 6.2-7.4 t/ha). The hybrids with FAO exceeding 350 should be used at the optimal irrigation and mineral nutrition because their yields are significantly superior to earlier ripening genotypes only in such technologies (yield 12.1-13.3 t/ha). The interaction of hybrid composition and moisture content was less noticeable compared to plant height and did not exceed $16 \%$. Therefore, by the feature of the "cob setting height" significantly greater differences were observed depending on the studied factors. The height of corn hybrid plants and the height of the cob setting have some specific dependencies on grain yield, which can be used as a marker feature in determination of the productivity of corn hybrids, their level of stability and adaptability to the conditions of mechanized harvesting. The manifestation of correlation can be greatly complicated by the influence of weather and moisture conditions. The height of corn plants, as well as the height of the cob setting, can serve as a marker of grain yield only under the conditions of optimal cultivation technology. Violation of the elements of technology can lead to mistaken conclusions.

\section{REFERENCES}

1. Лавриненко Ю.А., Гудзь Ю.В. Теория и практика адаптивной селекции кукурузы. Херсон: Борисфен-полиграфсервис, 1997. 170 с.

2. Лавриненко Ю.О., Коковіхін С.В., Найдьонов В.Г., Нетреба О.О. Селекційно-технологічні аспекти підвищення стійкості виробництва зерна кукурудзи в умовах південного Степу. Бюлетень Інституту зернового господарства. 2006. № 28-29. С. 136-143.

3. Олешко О.Г. Адаптивна характеристика гібридів кукурудзи, створених за участю лінії ДК 633/266-112. Бюлетень Інституту зернового господарства. 2003. № 21-22. С. 65-69.

4. Писаренко П.В., Григоренко Є.Я., Лавриненко Ю.О., Писаренко В.А. Продуктивність гібридів кукурудзи при різних умовах зволоження та густоті стояння рослин. Наукові проблеми виробництва зерна в Україні та сучасні методи їх вирімення. Дніпропетровськ. 2000. C. 82-83.

5. Eberhart S.A., Russell W.A. Stability parameters for comparing varieties. Crop Sci. 1966. Vol. 6, N 1. P. 36-40.

6. Кильчевский А.В., Хотылева Л.В. Метод оценки адаптивной способности и стабильности генотипов, дифференцирующей способности среды. Генетика. 1985. Т. ХХІ, № 9. С. 1481-1497.

7. Черчель В.Ю., Антонюк С.П., Олешко А.А., Дуда А.Н. Селекция скороспелых гибридов для Степи Украины. Бюлетень Інституту зернового господарства. 1997. № 3(5). С. 7-9.

8. Козубенко Л.В., Гурьева И.А. Селекция кукурузы на раннеспелость. Харьков, 2002. 239 с. 
9. Нетреба О.О., Лавриненко Ю.О. Успадкування та мінливість ознаки «висота рослин» у гібридів кукурудзи різних поколінь самозапилення, створених на базі ліній, контрастних за довжиною вегетаційного періоду. Зрошуване землеробство. 2005. Вип. 44. С. 99-102.

10. Домашнев П.П., Дзюбецкий Б.В., Костюченко В.И. Селекция кукурузы. Тр. ВАСХНИЛ. Москва: Агропромиздат, 1992. С. 11.

11. Мазур О.В. Селекційний матеріал для створення гібридів кукурудзи, придатних до механізованого обмолоту: автореф. дис. ... к-та с.-г.наук: 06.01.05. Київ: Інститут землеробства УААН, 2005. 19 с.

12. Лавриненко Ю.О., Плоткін С.Я. Мінливість кореляційної залежності адаптивних ознак у гібридів кукурудзи залежно від груп стиглості. Таврійський науковий вісник. 2005. Вип. 38. С. 17-23.

13. Vera G.A., Crane P.L. Effects of selection for lover ear height in synthetic populations of maize. Crop Sci. 1970. № 10. P. 286-288.

14. Мартиненко О.І. Ріст і адаптація рослин: кількісний підхід. Селекція і генетика в Україні на межі тисячоліть. Київ: Логос, 2001. Том 2. C. 115-122.

\section{Information about the author:} Naidionov V. H., Candidate (Ph.D.) of Agricultural Sciences, Senior Researcher of the State enterprise "Research Farm"Askaniiske" of Askanian State Agricultural Research Station of the Institute of Irrigated Agriculture of the National Academy of Agrarian Sciences of Ukraine Tavrychanka village, Kakhovka District, Kherson Region, 74862, Ukraine 